\title{
Asymmetric Intermolecular Heck Reaction of Aryl Halides by Pd-histidine Organocatalysts
}

\author{
Abdol Reza Hajipour ${ }^{1,2, \text { * , Zahra Khorsandi }}{ }^{1, ~ *}$ \\ ${ }^{1}$ Department of Chemistry, Isfahan University of Technology, Isfahan, Iran \\ ${ }^{2}$ Department of Neuroscience, University of Wisconsin, Madison, USA
}

Email address:

haji@cc.iut.ac.ir (A. R. Hajipour)

${ }^{*}$ Corresponding author

To cite this article:

Abdol Reza Hajipour, Zahra Khorsandi. Asymmetric Intermolecular Heck Reaction of Aryl Halides by Pd-histidine Organocatalysts. Modern Chemistry. Vol. 8, No. 2, 2020, pp. 18-22. doi: 10.11648/j.mc.20200802.11

Received: April 20, 2020; Accepted: May 5, 2020; Published: June 28, 2020

\begin{abstract}
Extensive studies of asymmetric intermolecular Heck reaction are described and provide a deeper insight into histidine-catalyzed. In particular, aspects of enantio- as well as diastereoselectivity of these reactions are discussed. As the first report, we synthesized five histidine-based organocatalyts including histidine as a well-defined and biodegradable natural structure alone and in combination with 2,4,6-trichloro-1,3,5-triazine, benzene-1,3-diamine, dimethyl malonate and dimeric structure applied in the asymmetric intermolecular Heck reaction of aryl halides; their efficiency was compared to each other's. These phosphine-free palladium catalysts were found as efficient catalytic system which provided the superior efficiency with excellent yields, regioselectivity and enantioselectivity. In these among, histidine with 2,4,6-trichloro-1,3,5-triazine which generate the star like molecule palladium catalyst gave the best activity in asymmetric intermolecular Heck reaction with excellent yields and good regio- and enantioselectivity under mild reaction conditions. The asymmetric intermolecular Heck reaction has been limited to aryl and vinyl triflates or aryl iodide in the rare reports of available Pd catalysts. Herein, we extend the reaction to aryl bromides. In addition, the scope of reaction was examined in two different techniques: conventional heating and microwave irradiation and compared. For the first time, microwave irradiation sintering is successfully used for this reaction. Comparison of catalytic activities of our catalyst $(\mathrm{Pd} / \mathrm{His})$ with literature examples confirmed our success.
\end{abstract}

Keywords: Heck, Asymmetric Reaction, Palladium, Organocatalytst, Histidine

\section{Introduction}

In recent years, asymmetric Heck reaction of aryl halides or aryl triflates with 2, 3-dihydrofuran have received considerable attention due to usages of some products in natural synthesis [1-2]. Up to now, numerous chiral catalytic systems for asymmetric Heck reaction of 2, 3-dihydrofuran with phenyl triflate were examined [3-5]; but, application of aryl halides, as more available substrates, in this coupling reaction is rare [6].

Amino acids are well-known as safe and green ligands for preparing asymmetric catalysts [7-10], such as proline/cyclobutane which used in asymmetric aldol additions, amino acid-containing peptide organocatalysts applying in asymmetric Michael addition [11], and conjugate addition reactions of aldehydes to maleimide [12-16].
However, to the best of our knowledge, asymmetric arylation of 2, 3-dihydrofuran employing histidine-based organocatalytst has never been reported.

The palladium catalyzed bond formation reaction between aryl halides and olefins bearing electron-withdrawing substituents (EWG, e.g. -COOR, $-\mathrm{CN}$ ) was studied extensively $[17,18]$, the Heck coupling involving an olefin bearing a hydrogen atom in the allylic position has proved to be a more challenging substrate. Some developments have been made in palladium catalyzed regioselective intermolecular arylation of dihydrofuran (DHF). [19-22] Unfortunately, the most of these conventional methods were limited to using phosphine ligands. [23-33] As we know, a few reports are available in P-free conditions for this type of reactions that suffer from low selectivity.

As a further extension of our ongoing work; [34-37] Herein we describe efficient and facile methods for 
intermolecular Heck reaction of aryl halides and 2, 3dihydrofuran which catalyzed by several histidine base Pdcatalytic systems. The structure of organocatalytst's ligands were represented in Scheme 1. The ligand 1 was found as the most efficient compound for asymmetric coupling reaction under thermal and microwave conditions with excellent ragio- and stereoselectivities. As we know, this is the first report of using phosphorus-free palladium catalyst in regioselective intermolecular Heck reaction of aryl halides with 2, 3-dihydrofuran.
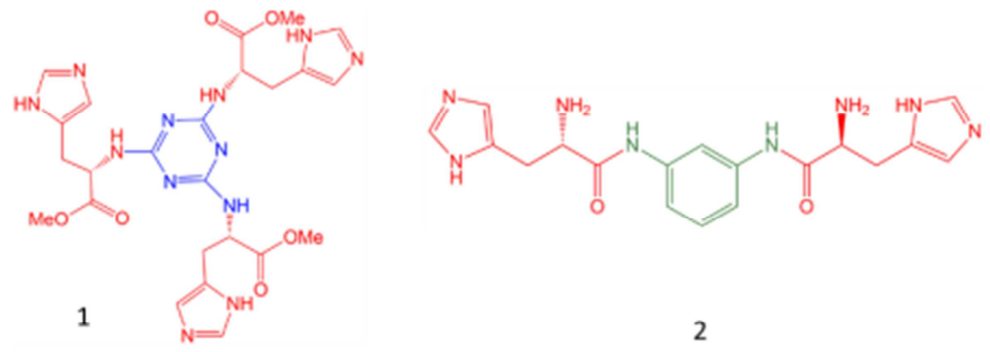<smiles>COC(=O)[C@H](Cc1cnc[nH]1)NC(=O)[C@H](N)Cc1cnc[nH]1</smiles><smiles>COC(=O)[C@H](N)Cc1ncc[nH]1</smiles>

4

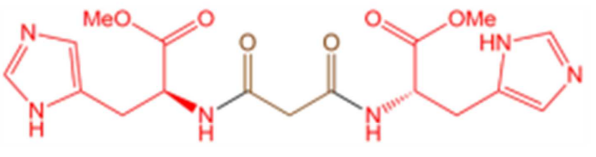

5

Figure 1. The structure of used histidine ligands.

\section{Results and Discussion}

Firstly, their catalytic efficiency in intermolecular Heck reaction of aryl halides with dihydrofuran were explored. To obtain the optimum experimental conditions, the Heck crosscoupling of 4-methoxyiodobenzene with 2, 3-dihydrofuran was chosen as a model reaction and various reaction conditions was explored. The results are summarized in Table 1. At first, the reaction was done applying different $\mathrm{Pd} / \mathrm{His}$ catalysts, as can be seen, ligand 1 gave the best results. In continues, various reactions conditions in presented of this ligand were optimized. Different solvents such as acetonitrile, ethanol, dimethyl sulfoxide and tetrahydrofuran were examined. The last one (THF) was found as the most effective solvent in reaction conversion, selectivity and enantioselectivity. After optimization of reaction temperature, $40^{\circ} \mathrm{C}$ was selected as sufficient heat. Among various base, $\mathrm{K}_{2} \mathrm{CO}_{3}$ was found as the most effected. The reaction was performed in THF with $\mathrm{K}_{2} \mathrm{CO}_{3}$ at $40{ }^{\circ} \mathrm{C}$ for $6 \mathrm{~h}$.

Table 1. Optimization conditions of the Heck reaction of iodobenzene with 2, 3-dihydrofuran. ${ }^{a}$

\begin{tabular}{|c|c|c|c|c|c|c|c|}
\hline 1 & 2 & & & 4 & & & \\
\hline Entry & Base & Solvent & $\mathbf{T}\left({ }^{\circ} \mathrm{C}\right)$ & Ligand $^{b}$ & Conv. $\%^{c}(3+4)$ & Selectivity $3 / 4(\%)$ & $e^{d}(\%)$ \\
\hline 1 & $\mathrm{~K}_{2} \mathrm{CO}_{3}$ & THF & 40 & 1 & 87 & 93 & 96 \\
\hline 2 & $\mathrm{~K}_{2} \mathrm{CO}_{3}$ & THF & 40 & 2 & 69 & 80 & 67 \\
\hline 3 & $\mathrm{~K}_{2} \mathrm{CO}_{3}$ & THF & 40 & 3 & 68 & 91 & 84 \\
\hline 4 & $\mathrm{~K}_{2} \mathrm{CO}_{3}$ & THF & 40 & 4 & 43 & n. d..$^{\mathrm{e}}$ & n. d. \\
\hline 5 & $\mathrm{~K}_{2} \mathrm{CO}_{3}$ & THF & 40 & 5 & 24 & n. d. & n. d. \\
\hline 6 & $\mathrm{~K}_{2} \mathrm{CO}_{3}$ & $\mathrm{CH}_{3} \mathrm{CN}$ & 40 & 1 & 12 & 89 & 90 \\
\hline 7 & $\mathrm{~K}_{2} \mathrm{CO}_{3}$ & $\mathrm{EtOH}$ & 40 & 1 & 38 & 81 & 83 \\
\hline 8 & $\mathrm{~K}_{2} \mathrm{CO}_{3}$ & DMSO & 40 & 1 & 59 & 70 & 86 \\
\hline 10 & $\mathrm{~K}_{2} \mathrm{CO}_{3}$ & THF & 60 & 1 & 88 & 93 & 89 \\
\hline 11 & $\mathrm{KOH}$ & THF & 40 & 1 & 90 & 85 & 93 \\
\hline 12 & $\mathrm{NaOH}$ & THF & 40 & 1 & 69 & 80 & 69 \\
\hline 13 & $\mathrm{Li}_{2} \mathrm{CO}_{3}$ & THF & 40 & 1 & 77 & 87 & 86 \\
\hline
\end{tabular}

${ }^{\mathrm{a}}$ Iodobenzene $(0.5 \mathrm{mmol}), 2$, 3-dihydrofuran $(1 \mathrm{mmol})$, solvent $(3 \mathrm{~mL})$ and base $(2 \mathrm{mmol}), 6 \mathrm{~h} ;{ }^{\mathrm{b}}$ with $0.04 \mathrm{~mol} \% \mathrm{PdCl}_{2} ;{ }^{\mathrm{c}} \mathrm{Conversion}$ percentages and selectivity was determined by GC [29]; ${ }^{\mathrm{d}}$ The enantioselectivity was measured by GC equipped with chiral column; ${ }^{\mathrm{e}}$ Due to low conversion, ragio-and enantio-selectivity were not detected. 
As shown herein, $\mathrm{Pd} / \mathrm{His}$ exhibits good catalytic activity and enantioselectivity, which is obtained in the mildest reaction conditions (low temperature and relatively shorter reaction times).

Using microwave irradiation, the reaction times was decreased remarkably. So, to further optimize the reaction conditions, the temperature and the MW power were also optimized and the best results were obtained using $\mathrm{K}_{2} \mathrm{CO}_{3}$, THF at $400 \mathrm{~W}$. The optimum temperature was found as 40 ${ }^{\circ} \mathrm{C}$. No increase in yield was observed at higher temperatures, while lowering the temperature below $40^{\circ} \mathrm{C}$ reduced the reaction rate. In continuous, the generality and versatility of this asymmetric palladium catalyst in regioselectivty arylation reaction of 2, 3-dihydrofuran cross-coupling of aryl halids was examined in two different techniques: conventional heating (method A) and MW irradiation (method B), were compared. As shown in Table 2, the microwave-assisted reactions were superior to those using conventional heating. It was observed that in both technics, some varieties of aryl halids with either electron-rich or electron-deficient substitutes reacted efficiently with 2, 3dihydrofuran and gave the corresponding products in moderate to good yields, ragio- and enantioselectivity. In general, high yields (80-99\%), good regioselectivity and excellent enantioselectivity are observed for aryl iodides and bromide substrates bearing either electron donating or electron-withdrawing substituents (entries 1-9). Actually, founding active substrates is one of the major limitations of this reaction; so, these results can be introduced as a success.

The obtain results was compared to various reported chiral catalysts for the asymmetric intramolecular Heck reaction arylation of 2, 3-dihydrofuran (Table 3). Almost of reported methods applied palladium catalyst with complex phosphine chiral ligands and in long reaction times.

Phenyl triflates were used as substrates in the typical process of the Heck arylation of 2, 3-dihydrofuran, the main disadvantage of triflate is easily hydrolysis. To the best of our knowledge, a few reports about stereoselective Heck coupling of 2, 3-dihydrofuran with aryl hides are available. Aryl hides are cheaper, more stable and more easily available substrates compared with triflates. Therefore, present procedure can be a valuable for the homochiral catalysts in asymmetric synthesis of derivatives of 2, 5-dihydro-2-phenylfuran.

One of the trends of the catalysis industry and green chemistry in environmental and economical point of view is scale-up synthesis. To gain insight into this issue, the Heck reaction of iodobenzen with 2, 3-dihydrofuran was selected and the scale of the reaction was increased to $10.0 \mathrm{mmol}$, keeping the reaction stoichiometry intact.

Table 2. Heck reactions of aryl halides with 2, 3-dihydrofuran. ${ }^{a}$

\begin{tabular}{|c|c|c|c|c|c|c|c|}
\hline 1 & 2 & & 4 & & & & \\
\hline \multirow{2}{*}{ Entry } & \multirow{2}{*}{$\mathbf{R} / \mathbf{X}$} & \multicolumn{3}{|l|}{ Method A } & \multicolumn{3}{|l|}{ Method B } \\
\hline & & Conv. ${ }^{\mathrm{b}}(\%)$ & Selectivity $^{\mathrm{b}} 3 / 4(\%)$ & $\operatorname{Ee}^{c}(\%)$ & Conv. ${ }^{\text {b }}(\%)$ & Selectivity ${ }^{\mathrm{b}}$ 3/4 (\%) & $\mathbf{E e}^{\mathrm{c}}(\%)$ \\
\hline 1 & $\mathrm{H} / \mathrm{I}$ & 87 & 93 & 93 & 89 & 92 & 93 \\
\hline 2 & $4-\mathrm{Cl} / \mathrm{I}$ & 83 & 91 & 94 & 86 & 92 & 90 \\
\hline 3 & $4-\mathrm{OMe} / \mathrm{I}$ & 85 & 88 & 91 & 84 & 86 & 92 \\
\hline 4 & $4-\mathrm{NO}_{2} / \mathrm{I}$ & 92 & 94 & 89 & 89 & 90 & 91 \\
\hline 5 & $\mathrm{H} / \mathrm{Br}$ & 79 & 89 & 93 & 81 & 86 & 89 \\
\hline 6 & 4-OMe / Br & 76 & 95 & 95 & 80 & 91 & 93 \\
\hline 7 & $4-\mathrm{NO}_{2} / \mathrm{Br}$ & 80 & 92 & 92 & 90 & 93 & 89 \\
\hline 8 & $4-\mathrm{Cl} / \mathrm{Br}$ & 81 & 90 & 89 & 87 & 89 & 94 \\
\hline 9 & 2-Bromonaphthalene & 90 & 92 & 94 & 93 & 91 & 92 \\
\hline 10 & $\mathrm{H} / \mathrm{Cl}$ & - & - & - & - & - & - \\
\hline
\end{tabular}

${ }^{\mathrm{a}}$ Iodobenzene $(0.5 \mathrm{mmol}), 2$, 3-dihydrofuran $(1 \mathrm{mmol})$, THF $(3 \mathrm{~mL})$ and $\mathrm{K}_{2} \mathrm{CO}_{3}(2 \mathrm{mmol}), 6 \mathrm{~h}$ in method A and 20 min in method $\mathrm{B}$; ${ }^{\mathrm{b}}$ Isolated yield; ${ }^{\mathrm{c}}$ Selectivity was determined by GC.[25] ${ }^{\mathrm{d}}$ The enantioselectivity was measured by chiral column GC.

\section{Conclusion}

This is the first report of applying oxidant- and phosphinefree catalyst in asymmetric Heck reaction of aryl halides with 2, 3-dihydrofuran. The reaction was found to proceed successfully, the corresponding product was obtained in good yields, high regio- and enantioselectivity at mild reaction conditions without inert atmosphere and phase transfer agents. In this work, we developed a novel palladium catalyst using palladium chloride salt and nitrogen rich histidin-based ligands $(\mathrm{Pd} / \mathrm{His})$ with cleaner reaction profiles and simple operation. 
Table 3. Comparison of catalytic activities of our catalyst (Pd/His) with literature examples.

\begin{tabular}{|c|c|c|c|c|c|c|}
\hline Entry [ref] & $\mathbf{X}$ & Catalytic system & Reaction conditions & Conv. (\%) & Selectivity & ee $(\%)$ \\
\hline $1[34]$ & I & $\mathrm{Pd}(\mathrm{OAc})_{2}(1 \mathrm{~mol} \%)$, Chiral IL, PhI & $\mathrm{DMF}, \mathrm{K}_{2} \mathrm{CO}_{3}, 70^{\circ} \mathrm{C}, 2 \mathrm{~h}$ & 100.0 & $70: 30$ & 4.2 \\
\hline $2[30]$ & $-\mathrm{OTf}$ & $\mathrm{Pd}(\mathrm{OAc})_{2}(1 \mathrm{~mol} \%), \mathrm{P}, \mathrm{O}-$ ligands & $\mathrm{THF},(\mathrm{i}-\mathrm{Pr})_{2} \mathrm{NEt}, 60^{\circ} \mathrm{C}, 3$ days & 68 & 20: 80 & 49.8 \\
\hline $3[31]$ & -OTf & $\mathrm{Pd}(\mathrm{OAc})_{2}(3 \mathrm{~mol} \%), 3,3$-Disubstituted xylBINAP & DIPEA, benzene, $40^{\circ} \mathrm{C}, 24 \mathrm{~h}$ & 32 & 10: 90 & 57 \\
\hline $4[35]$ & -OTf & $\mathrm{Pd}(\mathrm{dba})_{2}(3 \mathrm{~mol} \%), \mathrm{P}, \mathrm{O}$-ligands & $\mathrm{THF}, 60^{\circ} \mathrm{C},(\mathrm{i}-\mathrm{Pr})_{2} \mathrm{NEt}, 20 \mathrm{~h}$ & 75 & 94: 6 & 77.1 \\
\hline 5 [29] & -OTf & $\mathrm{Pd}(\mathrm{dba})_{2}$, ferrocenyl ligands & Toluene, $60^{\circ} \mathrm{C}, \mathrm{iPr}_{2} \mathrm{NEt}, 36 \mathrm{~h}$. & 99 & $97: 3$ & 80 \\
\hline $7[34]$ & $\mathrm{Br}$ & $\mathrm{Pd}_{2}(\mathrm{dba})(2.5 \mathrm{~mol} \%), \mathrm{Xyl}-\mathrm{SDP}(\mathrm{O})$ & $\left(\mathrm{CH}_{2} \mathrm{OH}\right)_{2}, 80^{\circ} \mathrm{C},(\mathrm{iPr})_{2} \mathrm{NEt}, 12 \mathrm{~h}$ & 84 & $91: 9$ & 91 \\
\hline $8[8]$ & I & Pd/DNA@MWCNTs & $\mathrm{THF}, 50^{\circ} \mathrm{C}, \mathrm{Li}_{2} \mathrm{CO}_{3}, 48 \mathrm{~h}$ & 92 & 87: 13 & - \\
\hline $\begin{array}{l}9 \text { [this } \\
\text { work] }\end{array}$ & $\mathrm{I}, \mathrm{Br}$ & $\mathrm{Pd} / \mathrm{His}$ & $\mathrm{THF}, 40^{\circ} \mathrm{C}, \mathrm{K}_{2} \mathrm{CO}_{3}, 6 \mathrm{~h}$ & 87 & 93: 7 & 93 \\
\hline
\end{tabular}

\section{Acknowledgements}

We gratefully acknowledge the funding support received from the Isfahan University of Technology (IUT), IR Iran.

\section{References}

[1] Ekpemo, S. C. (2018). Challenges and Outcome of Neonatal Surgery at the Abia State University Teaching Hospital Aba Nigeria. American Journal of Biomedical and Life Sciences, 6 (4), 69. doi: 10.11648/j.ajbls.20180604.11

[2] Hyder, Z.; Ruan, J. X. (2008). Hydrogen-Bond-Directed Catalysis: Faster, Regioselective and Cleaner Heck Arylation of Electron-Rich Olefins in Alcohols. Chemistry: A European Journal, $14 \quad$ (18), 5555. https://doi.org/10.1002/chem.200800411.

[3] Yang, Z.; Zhou, J. (2012). Palladium-Catalyzed, Asymmetric Mizoroki-Heck Reaction of Benzylic Electrophiles Using Phosphoramidites as Chiral Ligands. Journal of the American $\begin{array}{llll}\text { Chemical Society, } & 134 & \text { (29), } & 11833 .\end{array}$ doi.org/10.1021/ja304099j.

[4] Wu, C.; Zhou, J. (2014) Asymmetric Intermolecular Heck Reaction of Aryl Halides Journal of the American Chemical Society, 136 (2), 650-652. doi.org/10.1021/ja412277z

[5] Lauer, M. G.; Thompson, M. K.; Shaughnessy, K. H. (2014) Controlling Olefin Isomerization in the Heck Reaction with Neopentyl Phosphine Ligands. The Journal of Organic Chemistry, 79 (22), 10837-10848. doi.org/10.1021/jo501840u.

[6] Beletskaya, P.; Cheprakov, A. V. (2000) The Heck Reaction as a Sharpening Stone of Palladium Catalysis. Chemical review, 100 (8), 3009. doi.org/10.1021/cr9903048.

[7] Nicolaou, K. C.; Bulger, P. G; Sarlah D. (2005) Palladiumcatalyzed cross-coupling reactions in total synthesis. Angewandte Chemie International Edition, 44 (29), 4442. DOI: $10.1002 /$ anie. 200500368

[8] Magano J, Dunetz. J. (2011) Large-Scale Applications of Transition Metal-Catalyzed Couplings for the Synthesis of Pharmaceuticals. Chemical Reviews, 111 (3), 2177.

[9] Hajipour A R.; Khorsandi, Z.; Farrokhpour, H. (2016) Regioselective Heck reaction catalyzed by Pd nanoparticles immobilized on DNA-modified MWCNTs. RSC Advances, 6 (64), 59124.
[10] Miller, S. J. (2004) In Search of Peptide-Based Catalysts for Asymmetric Organic Synthesis, Accounts of Chemical Research, 37 (8), 601. doi.org/10.1021/ar030061c

[11] Yu, Z; Tantakitti Z, Palmer L, Stupp S. (2016) Asymmetric Peptide Nanoribbons, Nano Letters, 16 (11), 6967.

[12] Li, S.; Mehta, A. K, Sidorov, A. N.; Orlando, T. M.; Jiang, Z.; Anthony, N. R.; Lynn, D. G. (2016) Design of Asymmetric Peptide Bilayer Membranes, Journal of the American Chemical Society, 138 (10), 3579.

[13] Illa, O.; Porcar-Tost, O; Robledillo, C.; Elvira, C; Nolis, P.; Reiser, O.; Branchadell, V.; Ortuño, R. M. (2018) Stereoselectivity of Proline/Cyclobutane Amino AcidContaining Peptide Organocatalysts for Asymmetric Aldol Additions: A Rationale. The Journal of Organic Chemistry, 83 (1), 350 .

[14] Avila-Ortiz, C. G., Díaz-Corona, L.; González, E. J; Juaristi, E. (2017) Asymmetric Michael Addition Organocatalyzed by $\alpha, \beta$-Dipeptides under Solvent-Free Reaction Conditions, Molecules, 22, 1328. doi.org/10.3390/molecules22081328

[15] Grünenfelder, C. E; Kisunzu, J. K.; Wennemers, H. (2016) Peptide-Catalyzed Stereoselective Conjugate Addition Reactions of Aldehydes to Maleimide. Angew Chem Int Ed Engl.,18, 8571. 10.1002/anie.201602230.

[16] Sándor, B. Ö.; István, M. M.; Ferenc, F. (2012) Asymmetric aldol reaction in a continuous-flow reactor catalyzed by a highly reusable heterogeneous peptide. Journal of Catalysis. 295, 179. doi.org/10.1016/j.jcat.2012.08.006

[17] Tsogoeva, S. B.; Shengwei, W. (2005) (S)-Histidine-based dipeptides as organic catalysts for direct asymmetric aldol reactions, Tetrahedron: Asymmetry, 16 (11), 1947. DOI: 10.1016/j.tetasy.2005.04.027

[18] Soai, K.; Niwa, S.; Yamada, Y.; Inoue H. (1987) Chiral piperazine as a new chiral catalyst for the enantioselective addition of dialkyl zincs to aryl aldehydes, Tetrahedron Letter, 28 (41), 4841. doi.org/10.1016/S0040-4039(00)96639-5.

[19] Kawasaki, T.; Omine, T.; Suzuki, K.; Sato, H.; Yamagishi, A.; Soai, K. (2009) Highly enantioselective asymmetric autocatalysis using chiral ruthenium complex-ion-exchanged synthetic hectorite as a chiral initiator, Organic Biomoleculat Chemistry, 7 (6), 1073. doi.org/10.1016/S00404039(00)96639-5.

[20] Heck, R. F. (1979) Palladium-catalyzed reactions of organic halides with olefins, Accounts of Chemical Research, 12 (4), 146. doi.org/10.1021/ar50136a006 
[21] Nabid, M. R.; Bide, Y. (2014) H40-PCL-PEG unimolecular micelles both as anchoring sites for palladium nanoparticles and micellar catalyst for Heck reaction in water, Applied $\begin{array}{llll}\text { Catalysis } & \text { A: } & \text { General. } & 469,\end{array}$ doi.org/10.1016/j.apcata.2013.09.016.

[22] Wang, Y.; Yang, Q.; Yang, L.; Shi, J.; Zhang, M. (2013) $\mathrm{CuI} / \mathrm{TBAB}$ as a novel efficient catalytic system for Heck reaction in water, RSC Advances, 3 (44), 21251. doi.org/10.1039/C3RA44819C

[23] Yang, F.; Fu, S. Y.; Chu, W.; Li, C.; Tong, D. G. (2014) Monodisperse amorphous CuB23 alloy short nanotubes: novel efficient catalysts for Heck coupling of inactivated alkyl halides and alkenes, RSC Advances, 4 (86), 45838. doi.org/10.1039/C4RA08517E

[24] Jeffery, T.; David, M. (1998) [Pd/Base/QX] catalyst systems for directing Heck-type reactions, Tetrahedron Letters, 39 (32), 5751. doi.org/10.1016/S0040-4039(98)01135-6

[25] Sabino, A. A.; Machado, A. H. L, Correia, C. R. D.; Eberlin, M. N. (2004) Probing the mechanism of the Heck reaction with arene diazonium salts by electrospray mass and tandem mass spectrometry. Angewandte Chemie Int. Ed., 43 (34), 2514. doi.org/10.1002/anie. 200353076

[26] Rosol, M.; Moyano, A. (2005) 1'-Carbopalladated-4ferrocenyl-1,3-oxazolines as catalysts for Heck reactions: Further evidence in support of the $\mathrm{Pd}(0) / \mathrm{Pd}(\mathrm{II})$ mechanism, Journal of Organometallic Chemistry, 690 (9), 2291. DOI: 10.1016/j.jorganchem.2005.02.035

[27] Machado, A. H. L.; Sousa, M. A.; Patto, D. C.; Azevedo, S. L.; Bombonato, F. S. F.; Correia, C. R. D. (2009) The scope of the Heck arylation of enol ethers with arenediazonium salts: a new approach to the synthesis of flavonoids, Tetrahedron Letters, 50 (11), 1222. doi.org/10.1016/j.tetlet.2009.01.017.

[28] Fontanilla, D.; Johannessen, M.; Hajipour, A. R.; Cozzi, N.; Jackson, V. M. B; Ruoho, A. E. (2009) The Hallucinogen N,N-Dimethyltryptamine (DMT) Is an Endogenous Sigma-1 Receptor Regulator, Science, 323 (5916), 934. doi: $10.1126 /$ science. 1166127 .

[29] Tu, T.; Deng, W.P.; Hou, X. L.; Dai, L. X.; Dong, X. C. (2003) The Regioselectivity of the Asymmetric Intermolecular Heck Reaction with Planar Chiral Diphosphine-Oxazoline Ferrocenyl Ligands, Chemistry-A European journal, 9 (13), 3073. doi.org/10.1002/chem.200204450.
[30] Dai, W. M.; Yeung, K. K. Y.; Wang, Y. (2004) The first example of atropisomeric amide-derived P,O-ligands used for an asymmetric Heck reaction, Tetrahedron, 60 (20), 4425. DOI: $10.1016 /$ j.tet.2004.02.062.

[31] Rankic, D. A.; Lucciola, D.; Keay, B. A. (2010) Application of 3,3'-disubstituted xylBINAP derivatives in inter- and intramolecular asymmetric Heck/Mizoroki reactions, Tetrahedron Letters, 51 (43) 5724. DOI: 10.1016/j.tetlet.2010.08.078.

[32] Hou, X. L.; Dong, D. X.; Yuan, K. (2004) Synthesis of new chiral benzylically substituted P,N-ligands and their applications in the asymmetric Heck reaction, Tetrahedron: $\begin{array}{llll}\text { Asymmetry, } & 15 & (14), & 2189 .\end{array}$ 10.1016/j.tetasy.2004.05.030.

[33] Roszak, R.; Trzeciak, A. M.; Pernak, J.; Borucka, N. (2011) Effect of chiral ionic liquids on palladium-catalyzed Heck arylation of 2,3-dihydrofuran, Applied Catalysis A: General, 409, 148. doi.org/10.1016/j.apcata.2011.09.038.

[34] Hajipour, A. R.; Rezaei, F.; Khorsandi, Z. (2017) Pd/Cu-free Heck and Sonogashira cross-coupling reaction by Co nanoparticles immobilized on magnetic chitosan as reusable $\begin{array}{lllll}\text { catalyst, green chemistry, } 19 & \text { (5), } 1353 .\end{array}$ doi.org/10.1039/C6GC03377F.

[35] Hajipour, A. R.; Khorsandi, Z. (2016) Immobilized Pd on (S)methyl histidinate-modified multi-walled carbon nanotubes: a powerful and recyclable catalyst for Mizoroki-Heck and Suzuki-Miyaura $\mathrm{C}-\mathrm{C}$ cross-coupling reactions in green solvents and under mild conditions, Applied Organometallic Chemistry, 30 (5), 256. doi.org/10.1002/aoc.3425.

[36] Hajipour, A. R, Tadayoni, N. S.; Khorsandi, Z. (2016) Magnetic iron oxide nanoparticles-N-heterocyclic carbenepalladium (II): a new, efficient and robust recyclable catalyst for Mizoroki-Heck and Suzuki-Miyaura coupling reactions, Applied Organometallic Chemistry, 30 (7), 590. doi.org/10.1002/aoc.3475.

[37] Hajipour, A. R.; Khorsandi, Z. (2016) A comparative study of the catalytic activity of Co- and $\mathrm{CoFe}_{2} \mathrm{O}_{4}-\mathrm{NPs}$ in $\mathrm{C}-\mathrm{N}$ and $\mathrm{C}-$ $\mathrm{O}$ bond formation: synthesis of benzimidazoles and benzoxazoles from o-haloanilides, New Journal of Chemistry, 40 (12), 10474. doi.org/10.1039/C6NJ02293F. 